\title{
The Role of Information for Consumers in The Digital Era (Indonesia Case)
}

$* * *$

\section{Dijital Çağda Tüketiciler İçin Bilginin Rolü (Endonezya Örneği)}

\author{
Dr. Lucky Nugroho \\ Universitas Mercu Buana, Jakarta, Indonesia, lucky.nugroho@mercubuana.ac.id \\ ORCID: 0000-0002-9613-1667
}

\begin{abstract}
The development of technology during industrial revolution 4.0 is an inevitability. Therefore, this conceptual paper aims to analyze the influence of consumer information and knowledge in the digital era. The research method used is qualitative descriptive, namely conducting a literature review sourced from scientific articles and books related to the research object of this conceptual paper. Based on the research results on this conceptual paper, in today's digital era, consumer behavior has undergone significant changes where digital platforms have become a source of information for the public in making decisions. In addition, the information available on electronic social media can be received differently depending on the knowledge of the consumer.
\end{abstract}

Keywords: Digital Era, Consumer, Behavior, Information, Knowledge

JEL Codes: D12, D82, D91

\section{Özet}

Endüstri 4.0 devrimi ile birlikte teknolojinin gelişmesi kaçınılmaz olmuştur. Dolayısıyla makale, dijital çağda tüketici bilgisinin etkisini analiz etmeyi amaçlamıştır. Kullanılan araştırma yöntemi nitel tanımlayıcıdır. Bu sebeple, araştırma konusu ile ilgili olarak bilimsel makalelerden ve kitaplardan bir literatür taraması yapılmıştır. Araştırma sonuçlarına dayanarak, günümüz dijital çağında, dijital platformların karar vermede toplum için bir bilgi kaynağı haline geldiği ve tüketici davranışlarının önemli değişikliklere uğradığı söylenebilir. Ayrıca sosyal medyada platformlarında yer alan bilgiler, tüketici bilgisine bağlı olarak farklı şekilde algılanabilmektedir.

Anahtar Kelimeler: Dijital Çağ, Tüketici, Davranış, Bilgi

JEL Kodları: D12, D82, D91

\section{INTRODUCTION}

The development of technology is an inevitability and cannot be avoided. This is because human knowledge is always evolving and produces an innovation that aims to improve the value and performance of human activities (Boyd \& Holton, 2018; Mokyr et al., 2015). The industrial revolution demonstrates the development of human knowledge and innovation in business and industrial activities. The industrial revolution is the stages of innovation of the human mind that then impact the industrial and business sectors to contribute to the world's economic, social, and cultural conditions (Morrar et al., 2017). The stages of the industrial revolution that occurred in the world began with the discovery of tools that replaced human and animal activities or commonly called mechanization. The industrial revolution, early-stage or so-called industrial revolution 1.0 is indicated by changes in behavior in the use of tools such as steam engines as tools that support the production of goods, the use of steam engines to assist fishermen in sailing, and so on (Ślusarczyk, 2018).

Furthermore, the industrial revolution 2.0 was demonstrated by human innovation related to electricity as a means of power generation. This invention of electricity changed the behavior of humans who 
previously used a lot of steam power in their activities, then turned it into electricity as the primary source of power in the production process (Özüdoğru et al., 2018). Factories in the industrial revolution 2.0 show this phenomenon has implemented assembly lines in making goods such as car factories, weapons factories, electronics factories, etc. Human knowledge is dynamic that it is constantly evolving and finding computers as tools that can replace instructions carried out by humans. Industrial Revolution 3.0 changed human behavior, which had previously used humans as instructions in industrial processes replaced with computers such as semiconductors, transistors, and integrated chips (Vaidya et al., 2018).

Moreover, the development of industrial revolution 4.0 resulted from the invention of the internet that combines computer technology with mechanization. As a result, there are discoveries related to computer applications that can replace human activities (Witkowski, 2017). Some examples of discoveries in the industrial revolution 4.0 in Indonesia cases are Go-Jek, Traveloka, Tokopedia, etc. (Mumtaha \& Khoiri, 2019). This has an impact on changes in human behavior that rely on applications in daily activities and work.

Human dependence on technology in the industrial revolution 4.0 in all human activities is called the digital era. The digital age provides technology that helps all aspects of human life. Human dependence on technology in the digital age is getting stronger. Almost all human work activities today depend on email, the internet, computers, etc. Therefore, the development of digital technology has a significant impact on changes in economic activity in the world. As one of the countries with the largest population and in the industrialization phase, Indonesia has used the internet to support business and economic activities.

Referring to information submitted by the Indonesian Internet Service Providers Association of Indonesia's total population in 2019 amounting to 264 million people, as many as $64.8 \%$ have used internet services or a total of 171.07 million people (Pramono, 2019). In addition, based on the results of the survey from Kasyfi (2018), Internet use in economic activity includes:

- Price search and compare the price of a product amounting to $45.14 \%$ of the population or a total of 77.22 million people;

- Helps manage businesses at $41.04 \%$ of the population or 70.21 million people;

- Seeking information related to products and services amounting to $37.82 \%$ of the population or a total of 64.70 million people;

- Make online purchases amounting to $32.19 \%$ of the population or a total of 55.07 million people;

- Looking for job openings amounting to $26.19 \%$ of the population or a total of 44.80 million people;

- Conducting banking transactions amounting to $17.04 \%$ of the population or a total of 29.15 million people;

- Online buying and selling amounted to $16.83 \%$ of the population or a total of 28.79 million people.

Referring to the data mentioned above and the number of internet users based on the purpose of internet users based on economic activity, it can be known that the majority of internet use is to find information. For example, the information that the public is looking for using internet media is to look for the price of a product amounting to 77.22 million people or $45.14 \%$, looking for information related to the management of companies and businesses amounting to 70.21 million people or $41.04 \%$ and looking for information related to products and services amounting to 64.70 million people or $64.70 \%$. Thus, based on these data, most people in Indonesia in the current digital era have used the internet to seek information to make decisions in economic activity. 
Furthermore, information is input from knowledge; the more information a person receives, the more knowledge the person will receive (Brucks, 1985; Radecki \& Jaccard, 1995). On the other hand, companies must continue to innovate to develop their products and services based on the needs and desires of consumers and society in general. Therefore, in the making, marketing, and selling a product or service, the company must understand consumer behavior (Grunert \& Valli, 2001; Jansson et al., 2011). Meanwhile, the consumer's behavior is influenced by his knowledge and the information obtained (Mak \& Braspenning, 2012; Mura et al., 2013). Based on this phenomenon, the formulation of the problems in this article is as follows: (i) How can knowledge influence consumer behavior in the digital age?; (ii) How can consumer knowledge consumer decisions?

Furthermore, based on the formulation of the problem, the purpose of this conceptual article includes (i) analyzing the factors that influence consumer behavior in the digital era; (ii) analyzing the relationship between knowledge and consumer behavior and decision-making.

Furthermore, this article contributes to the characteristics of strategic management to be used as input from stakeholders and academics in strategizing in developing company products and services to be on target. Meanwhile, academics can be used as a reference in research and scientific work related to the management of corporate strategies to develop products and services according to the wants and needs of consumers in particular and society in general.

Furthermore, this article contributes to the characteristics of strategic management to be used as input from stakeholders and academics in strategizing in developing company products and services to be on target. Meanwhile, academics can be used as a reference in research and scientific work related to the management of corporate strategies to develop products and services according to the wants and needs of consumers in particular and society in general.

\section{METHOD}

The method used in this conceptual paper is descriptive in that conducting research objects based on phenomena and scientific literature related to research objects. In addition, to support the descriptive method, the study also used secondary data that is quantitative and has been published by institutions that have the authority to support the arguments in this study. Furthermore, the analysis technique in this study uses miles and Huberman models illustrated in the following image:

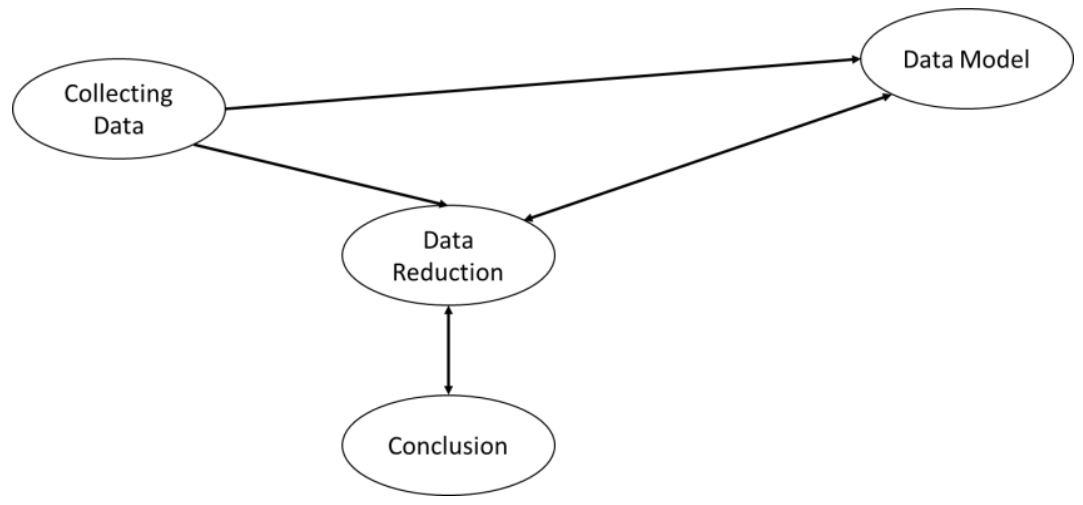

Figure 1. Miles and Hubermen Analysis Techniques (Emzir, 2016).

Based on figure 1 above, then in this conceptual paper, the stage is to collect data from previous scientific studies following the conceptual paper. If data is not appropriate, then data have to reduction. So that the data collected is appropriate and adequate to make decisions in the conceptual paper. Therefore, to limit the discussion on the conceptual paper, the research question of this research includes (i) How can 
knowledge influence consumer behavior in the digital age?; (ii) How can consumer knowledge influence consumer decisions?

Nevertheless, this article contributes to the characteristics of strategic management to be used as input from stakeholders and academics in strategizing in developing company products and services to be on target. Meanwhile, academics can be used as a reference in research and scientific work related to the management of corporate strategies to develop products and services according to the wants and needs of consumers in particular and society in general.

\section{FINDINGS}

\section{Consumer Knowledge and Consumer Behavior in the Digital Age}

Consumer knowledge is an essential asset for a company's business. This is because knowing consumer knowledge is the company's first step to developing its business by developing quality and product and service features so that customers meet their needs and desires (Rowley, 2002). Furthermore, consumer knowledge is all information owned by consumers related to various products and services and other information related to these products and services. In addition, there is also a definition that states that consumer knowledge is related to changes in the behavior of individuals or consumers as a result of the consumer's experience in using the product or service (Kotler \& Pfoertsch, 2007). While according to J. Paul et al. (1999) divide consumer knowledge into three criteria which include: (i) Consumer knowledge related to the specifications and attribute characteristics of a product or service; (ii) Consumer knowledge relating to the usefulness and benefits of a product or service; (iii) Consumer knowledge is concerned with experience and satisfaction with the use of a product or service.

With the current extraordinarily tight business competition conditions, companies need to know about their consumers. If the company has no or has little experience with consumer knowledge management, then the company is advised to perform the four stages described by the pyramid below:

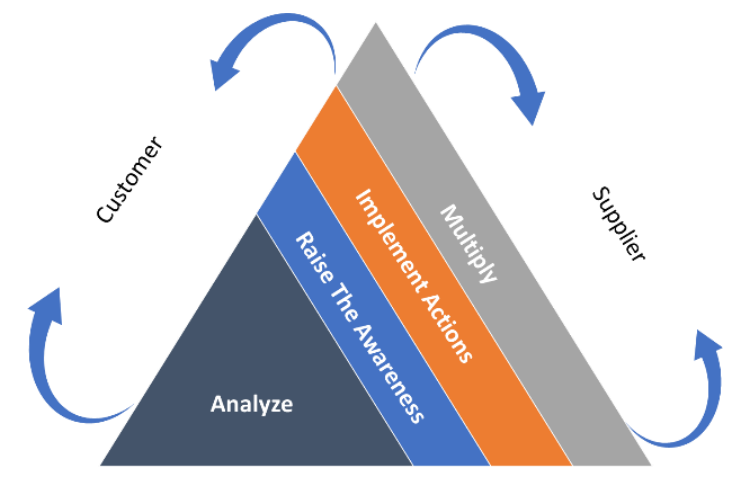

Individual/Employee

Figure 1. Pyramid of Knowledge Management (Wilde, 2011)

Referring to figure 1 above, the stages of the company to be able to analyze the knowledge (needs and desires) of consumers are as follows (Wilde, 2011):

- Conducting analysis related to knowledge of products or services owned by the company both in terms of consumers, suppliers, and employees (for example, by using questionnaires);

- Increase awareness of the results obtained from an analysis that aims to increase the needs and benefits of the company's products or services (e.g., by evaluating and correcting errors that have been made); 
- Based on the results of the evaluation, the company must make strategic and planning initiatives and implement them (e.g., by introducing knowledge databases or regular training);

- With the information that the company has related to the needs and desires of consumers, suppliers, and employees, the relevant information must be disseminated to relevant parties or work units that have the opportunity to improve the quality and benefits of the goods and services of the company (by using the database of goods and services of the company).

The development of internet use is now an inevitability, so that it can be said that companies face new challenges in this digital era. To survive in this digital era, the relationship with consumers becomes very vital. Relationships with consumers can be built through marketing services and marketing communication. In line with the digital era, the company is required to develop E-Business. E-Business is an application or channel used to find out the experience of consumers in using the products and services of the company. In addition, the company must increase the use of E-Business by knowing the needs and desires of consumers based on the knowledge or information they have. Therefore, the company must consider several things related to the information needed, namely:

Knowledge of the consumer, which may include knowledge of potential consumers and their segmentation as well as knowledge of individual consumers;

The knowledge possessed by consumers is related to product ranges, such as compatibility between computer hardware components or the efficacy of a particular drug, and about the context and broader market in which products and services are provided.

Thus to be able to know the knowledge of consumers to maintain relationships, and perform marketing services (marketing services) and marketing communication (marketing communication) in the digital era, then a company needs to carry out information technology systems that accommodate the following functions:

- E-commerce;

- Channel automation software;

- Collaborative commerce software;

- Online storefront;

- Multichannel customer management;

- E-service;

- E-mail response management;

- Guided selling and buying;

- Product configuration;

- Order management;

- Electronic agents;

- Catalog management;

- Content management;

- E-customer;

- Fulfillment software; and

- Self-service.

Therefore, the technology information system must be integrated into the company's operational or business activities. Furthermore, the information system technology will translate data into knowledge 
that increases customer value, without human intervention. In general, data is not information and indeed not knowledge. Data needs to be processed to turn it into information or knowledge to impact organizational learning and change organizational behavior. (Rowley, 2002).

Furthermore, consumer behavior is the action of consumers in determining the choice or decision-making process to choose a product or service that suits their needs and desires. Some theories related to the notion of consumer behavior based on previous research are as follows:

- Consumer behavior is a process of stimulation to prospective consumers to motivate prospective consumers to make purchases. In addition, consumer behavior also includes experience in using products and services so that there is feedback or evaluation for the process of developing these products and services (Nicosia, 1966);

- Consumer behavior is a system device that includes: process stimuli, information processing, decision-making process, information search process, post-decision evaluation process, and related external factors (Kollat et al., 1972);

- Consumer behavior includes mechanisms: input variables in the form of external stimuli and internal stimuli, output variables in the form of attention, attitudes, and desires, which are supported by learning and the formation of perception. In addition, there are also exogenous variables in the form of satisfaction and choice over the products and services offered (Howard \& Sheth, 1969);

- Consumer behavior includes mechanisms: input variables in the form of external stimuli and internal stimuli, output variables in the form of attention, attitudes, and desires, which are supported by the process of learning and the formation of perception. In addition, there are also exogenous variables in the form of satisfaction and choice over the products and services offered (Bettman, 1979);

- Consumer behavior includes several processes that include: input process, namely the process of disbursement of information in the form of exposure, perception, and retention; the decisionmaking process, which is the process of analyzing and evaluating the information that subsequently produces a decision; and variables that affect the individual, social and cultural character that a person believes in (Sheth, Newman, \& Gross, 1991).

Consumer decision-making parameters in the digital age have undergone significant changes from previous eras. Today consumers have a sensitivity to several variables such as price and quality. The existence of the internet has empowered the community and is aware of the availability of products of better quality at affordable prices. As a result, the Internet has impacted the development of E-Commerce. E-Commerce is an online sales transaction that includes online retail sales, online banking transactions, and online shopping.

Previous research has also stated that the internet has become a significant source of information when making purchasing decisions (Kim et al., 2008; Teo \& Yeong, 2003). In today's digital era, almost all goods and services can be sold online through the internet, ranging from cars, homes, motorcycles, used goods, electronics to food and beverages, even reflexology. Nevertheless, according to Luo et al. (2011) dan Sexton et al. (2002), some sectors are most exposed or affected, namely the education, entertainment, and consulting services sectors. Following these conditions, the company is required to adjust its sales strategy through online media. Refer to research conducted by Choi et al. (2002), who compares the use of the web-online and those who do not use the web-online in the sales process in a company, it is known from the results of his research that shows that companies that sell their goods using the web-online have doubled compared to companies that have not used web-online in their sales mechanism. In addition, the 
banking industry in the UK has a 15\% share of insurance sales online (Chaffey \& Smith, 2013). This is because most people in the digital era buy products and services purchased because they look for information online. Before consumers decide to buy, those prospective buyers will conduct an online search to gather price information and special offers before visiting stores and showrooms or calling by phone to negotiate a better deal. Therefore, in the current digital era, companies must provide sales mechanisms or information related to their products and services online. The addition of these facilities will accommodate the needs of the public in the digital era to make purchases and search for information online. This is evidenced by the BMW company, that about $50 \%$ of prospective buyers who do test drives are generated from their website (Chaffey \& Smith, 2013). In addition, electronic social media has a significant contribution to the development of online transactions (Hansen et al., 2018).

\section{The Role of Consumer Knowledge in Decision Making}

According to Yulianti (2016), lack of information will reduce the public's interest to use products or services offered by a company or organization. So that information has a vital role in decision making to choose goods or services according to needs and wants. Furthermore, there are several definitions related to information, among others:

- Information is data that has been processed into something valuable and essential for the recipient and its users and valuable to take alternative decisions that are right for now or in the future (Amalia, 2013; McLaughlin et al., 1983);

- Information is data or facts that have been processed and processed systematically, thus producing relevant information. Therefore, information can be used to reduce uncertainty and have benefits in choosing alternative decisions with the lowest risk (Anggadini, 2014);

- According to McLeod \& MacDonell (2011), information is one of the data sources processed using an application or computer whose results can systematically solve existing problems.

- Following the definition above, information is the result of systematic data processing so that the data has value to be used in decision making. Furthermore, information with knowledge has a close relationship. Knowledge is the ability to decide that the alternatives of information obtained can be used appropriately to provide solutions and reduce the risks. Thus, the more information that a person has, it will impact increasing the knowledge he has. According to Purnamasari (2013), knowledge is information that a person has, so it can be said to process and access data into information. In addition, knowledge is also obtained from the process of education and experience of a person (Futri \& Juliarsa, 2014). Therefore, when connected between data, information, knowledge, experience, and education, it can be illustrated in figure 2 below:

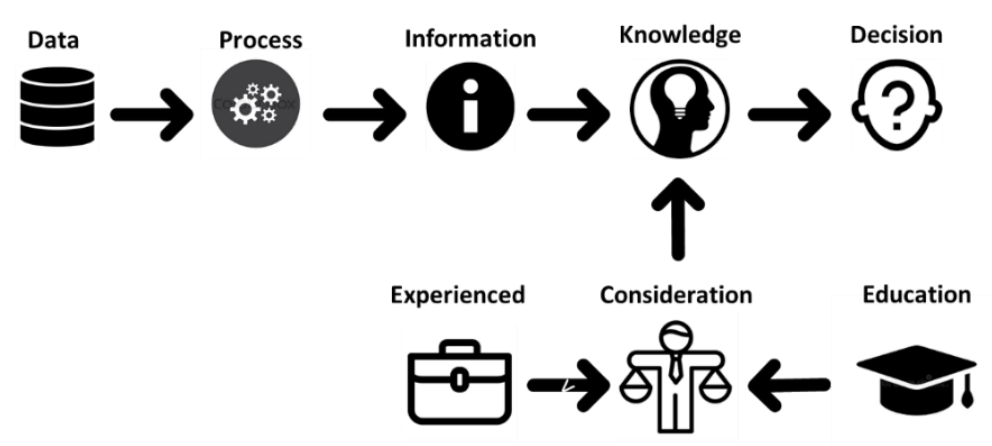

Figure 2. Decision-Making Process (Author). 
The right decision helps solve the problem and has minimal risk for the future, requiring a mechanism as shown in figure 2 above. Furthermore, for a product or service to be in demand by prospective buyers or the public, activity is needed to disseminate, convey and communicate the information using verbal, audio, and visual media (Gumilar \& Zulfan, 2017). Therefore, the promotion has a vital role in marketing a product or service because promotion is one of the determinants of the success of a marketing program in a company. According to (Indah \& Yulianto, 2011; Maimunah et al., 2012), promotion is a form of marketing communication to the public or prospective users of products and services that seek to disseminate information, influence or persuade and remind the target market of its products and services to be willing to accept and loyal to the products or services offered by the company concerned. Thus, promotion is an internal effort of the company to communicate information on the products or services it has to be accepted and used by the community. In addition, promotion can also be a tool in competing to convey the advantages of products and services owned by a company compared to its competitors.

Knowledge means everything that is known to be related to information (Bairizki et al., 2021; Hidayah et al., 2020; Nisak et al., 2013). Knowledge is also information about specific or universal methods, processes, patterns, and resource structures (Nugroho et al., 2018; Yazdi, 2012). Knowledge is influenced by many things, including formal education and informal education. A person's knowledge of an object contains two aspects, namely positive and negative aspects. These positive and negative aspects will determine a person's attitude. The more positive aspects, the more positive the attitude of prospective customers towards the object. Knowledge related to the product or service refers to the statement Peter et al. (1999), include:

- Knowledge related to the characteristics or attributes of a product or service for customers and the public;

- Knowledge related to the benefits of products or services for customers and the public;

- Knowledge related to adding value and satisfaction provided by-products or services for customers and the public.

Knowledge related to adding value and satisfaction provided by-products or services for customers and the public Kotler (1994) Interest is a person's situation before taking action, which can be used as a basis for predicting a person's behavior or actions. For example, the interest in partnering with Islamic banks assumed to be an interest in using Islamic bank products and services is behavior that arises in response to objects that indicate the consumer's desire to use them. Knowledge is an external factor for the organization or company so that the information received is positive so that their interest in using the company's products and services also increases. The relationship between promotion, information, knowledge, and interest can be illustrated in figure 3 below:

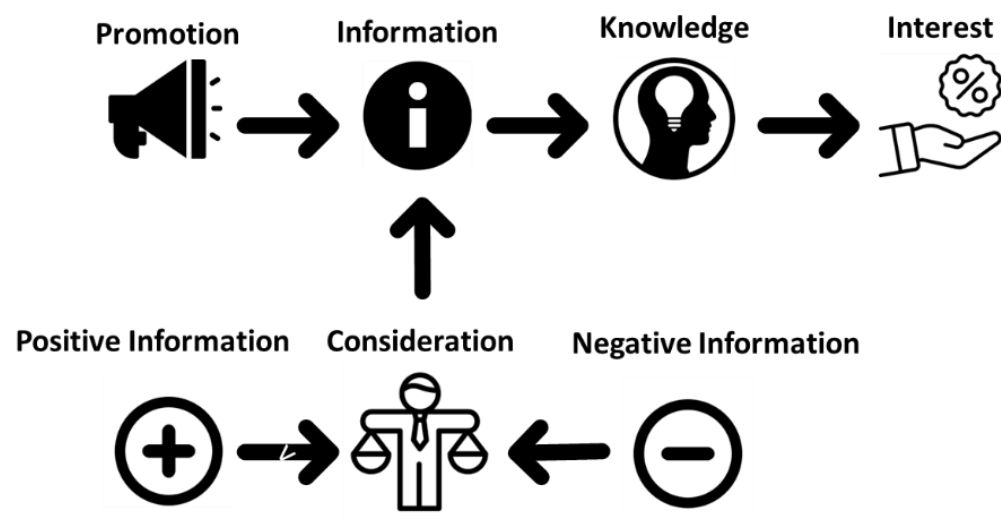

Figure 3. Promotional Relationships, Knowledge, and Interests to Attract Customers (Author). 
Referring to figure 3 above, promotion helps increase the dissemination of information related to the products and services of a product and service so that the public can receive positive information based on the knowledge they have that can ultimately increase interest in using products and services. The increasing interest in the use of products and services of a product and service will impact the decision of consumers to become buyers of products or service users. In today's digital era, promotional channels no longer go through traditional media such as radio, television, magazines, etc., but have proliferated through electronic media. Internet marketing is one of the tools in marketing communication that is currently widely used as a new medium in marketing. One of which is by utilizing the popularity of social media as a medium of promoting (Lestari, 2015).

\section{CONCLUSION AND RECOMMENDATIONS}

In today's digital age, consumer behavior has undergone significant changes where digital platforms have become a source of information for people to make decisions. In addition, the information available on electronic social media can be received differently depending on the knowledge of the consumer. Furthermore, to increase the probability of using a company's products and services required promotion to affect one's attitude and motivation to buy the products and services offered. However, the process of consumer behavior is not only limited to the process of purchasing decision making but also the process of knowing the experience of the buyer that can be used as an input and evaluation to improve the products and services under the needs and desires of the community today and in the future.

\section{REFERENCES}

Amalia, N. (2013). Pemeringkatan obligasi PT Pefindo: Berdasarkan informasi keuangan. Accounting Analysis Journal, 2(2), 140-147.

Anggadini, S. D. (2014). Mekanisme Pengawasan Dewan Pengawas Syariah dan Bank Indonesia terhadap Bank Syariah. Majalah Ilmiah Unikom, 12(1), 77-84.

Bairizki, A., Irwansyah, R., Arifudin, O., Asir, M., Ganika, W. G., Karyanto, B. \& Marietza, F. (2021). Manajemen Perubahan. Widina Bhakti Persada Bandung.

Bettman, J. R. (1979). Memory Factors in Consumer Choice: A Review. Journal of Marketing, 43(2), 37-53.

Boyd, R. \& Holton, R. J. (2018). Technology, innovation, employment and power: Does robotics and artificial intelligence really mean social transformation? Journal of Sociology, 54(3), 331-345. https://doi.org/10.1177/1440783317726591

Brucks, M. (1985). The Effects of Product Class Knowledge on Information Search Behavior. Journal of Consumer Research, 12(1), 1-16. https://doi.org/10.1086/209031

Chaffey, D. \& Smith, P. (2013). Emarketing Excellece: Planning and optimizing your digital marketing. The New England journal of medicine (4th ed.). Routledge. https://doi.org/10.1056/NEJM196104062641401

Choi, J. J., Laibson, D. \& Metrick, A. (2002). How does the internet affect trading? Evidence from investor behavior in 401(k) plans. Journal of Financial Economics, 64(3), 397-421. https://doi.org/10.1016/S0304405X(02)00130-7

Emzir. (2016). Analisis Data. PT Raja Grafindo Persada.

Futri, P. S. \& Juliarsa, G. (2014). Pengaruh Independensi, Profesionalisme, Tingkat Pendidikan, Etika Profesi, Pengalaman, dan Kepuasan Kerja Auditor pada Kualitas Audit Kantor Akuntan Publik di Bali. E-Jurnal Akuntansi Universitas Udayana, 7(2), 444-461. https://doi.org/10.1111/j.1365-2761.1986.tb01041.x

Grunert, K. G. \& Valli, C. (2001). Designer-made meat and dairy products: Consumer-led product development. In Livestock Production Science (Vol. 72, pp. 83-98). Elsevier. https://doi.org/10.1016/S0301-6226(01)00269-X

Gumilar, G. \& Zulfan, I. (2017). Penggunaan Media Massa Dan Internet Sebagai Sarana Penyampaian Informasi Dan Promosi Oleh Pengelola Industri Kecil Dan Menengah Di Bandung. Jurnal Kajian Komunikasi, 2(1), 8592. https://doi.org/10.24198/jkk.vol2n1.9

Hansen, J. M., Saridakis, G. \& Benson, V. (2018). Risk, trust, and the interaction of perceived ease of use and 
behavioral control in predicting consumers' use of social media for transactions. Computers in Human Behavior, 80, 197-206. https://doi.org/10.1016/j.chb.2017.11.010

Hidayah, N., Badawi, A., Nugroho, L. \& Prihanto, H. (2020). Human Capital and The Use Of Information Technology To Enhance Sustainable Competitive Advantages (Case study on Sharia Banking). Archives of Business Review, 8(6), 239-249. https://doi.org/10.14738/abr.86.8536

Howard, J. A. \& Sheth, J. N. (1969). The Theory of Buyer Behavior. John Wiley and Sons.

Indah, I. N. \& Yulianto, L. (2011). Pembuatan Website Sebagai Sarana Promosi Produk Kelompok Pidra Desa Gawang Kecamatan Kebonagung Kabupaten Pacitan. Journal Speed, 3(4), 30-33. https://doi.org/10.3112/SPEED.V3I4.1155

Jansson, J., Marell, A. \& Nordlund, A. (2011). Exploring consumer adoption of a high involvement eco-innovation using value-belief-norm theory. Journal of Consumer Behaviour, 10(1), 51-60. https://doi.org/10.1002/cb.346

Kasyfi, H. (2018). APJII: Penetrasi Pengguna Internet Indonesia Capai 143 Juta Orang | Dailysocial. Retrieved January 25, 2020, from https://dailysocial.id/post/apjii-survei-internet-indonesia-2017

Kim, D. J., Ferrin, D. L. \& Rao, H. R. (2008). A trust-based consumer decision-making model in electronic commerce: The role of trust, perceived risk, and their antecedents. Decision Support Systems, 44(2), 544-564. https://doi.org/10.1016/j.dss.2007.07.001

Kollat, D. T., Blackwell, R. D. \& Engel, J. F. (1972). The current status of consumer behavior research: Developments during the 1968-1972 period. ACR Special Volumes.

Kotler, P. (1994). Reconceptualizing marketing: An interview with Philip Kotler. European Management Journal, 12(4), 353-361. https://doi.org/10.1016/0263-2373(94)90021-3

Kotler, P. \& Pfoertsch, W. (2007). Being known or being one of many: The need for brand management for business-to-business (B2B) companies. Journal of Business \& Industrial Marketing, 22(6), 357-362. https://doi.org/10.1108/08858620710780118

Lestari, D. P. (2015). Analisis Strategi Internet Marketing Butik Online Di Surabaya Melalui Instagram. Jurnal Commonline Departemen Komunikasi, 4(2), 412-424.

Luo, M. M., Chea, S. \& Chen, J. S. (2011). Web-based information service adoption: A comparison of the motivational model and the uses and gratifications theory. Decision Support Systems, 51(1), 21-30. https://doi.org/10.1016/j.dss.2010.11.015

Maimunah, Sunarya, L. \& Nina Larasati. (2012). Media Company Profile Sebagai Sarana. CCIT Journal, 5(40), 281-301.

Mak, V. \& Braspenning, J. (2012, September 30). Errare humanum est: Financial Literacy in European Consumer Credit Law. Journal of Consumer Policy. Springer. https://doi.org/10.1007/s10603-012-9198-5

McLaughlin, B. Rossman, T., \& McLeod, B. (1983). Second Language Learning: an Information-Processing Perspective. Language Learning, 33(2), 135-158. https://doi.org/10.1111/j.1467-1770.1983.tb00532.x

Mokyr, J., Vickers, C. \& Ziebarth, N. L. (2015). The history of technological anxiety and the future of economic growth: Is this time different? Journal of Economic Perspectives, 29(3), 31-50. https://doi.org/10.1257/jep.29.3.31

Morrar, R., Arman, H. \& Mousa, S. (2017). The Fourth Industrial Revolution (Industry 4.0): A Social Innovation Perspective. Technology Innovation Management Review, 7(11), 12-20. https://doi.org/10.22215/TIMREVIEW/1396

Mumtaha, H. A. \& Khoiri, H. A. (2019). Analisis Dampak Perkembangan Revolusi Industri 4.0 dan Society 5.0 Pada Perilaku Masyarakat Ekonomi (E-Commerce). JURNAL PILAR TEKNOLOGI : Jurnal Ilmiah Ilmu Ilmu Teknik, 4(2), 55-60. https://doi.org/10.33319/piltek.v4i2.39

Mura, M., Lettieri, E., Radaelli, G. \& Spiller, N. (2013). Promoting professionals' innovative behaviour through knowledge sharing: The moderating role of social capital. Journal of Knowledge Management, 17(4), 527544. https://doi.org/10.1108/JKM-03-2013-0105

Nicosia, F. M. (1966). Consumer Decision Processes; Marketing and Advertising Implications. Englewood Cliffs, NJ: Prentice-Hall.

Nisak, A., Saryadi. \& Suryoko, S. (2013). Pengaruh Kelompok Acuan dan Pengetahuan tentang Perbankan Syariah terhadap Minat Menabung di Perbankan Syariah Semarang. Jurnal Ilmu Administrasi Bisnis , 1(1), 44-50. 
Nugroho, L., Utami, W., Sanusi, Z. M., \& Setiyawati, H. (2018). Corporate Culture and Financial Risk Management in Islamic Social Enterprises (Indonesia Evidence). International Journal of Commerce and Finance (Vol. 4).

Özüdoğru, A. G., Ergün, E., Ammari, D. \& Görener, A. (2018). How industry 4.0 changes business: A commercial perspective. International Journal of Commerce and Finance, 4(May 2019), 84-95.

Peter, J.P, Olson, J. . \& Grunert, K. . (1999). Consumer Behaviour and Marketing Strategy (Vol. 3). McGraw-Hill.

Pramono, Y. (2019). APJII: Jumlah Pengguna Internet di Indonesia Tembus 171 Juta Jiwa. Retrieved March 17, 2020, from https://tekno.kompas.com/read/2019/05/16/03260037/apjii-jumlah-pengguna-internet-diindonesia-tembus-171-juta-jiwa

Purnamasari, D. (2013). Pengaruh Etika Auditor, Pengalaman, Pengetahuan Dan Perilaku Disfungsional Terhadap Kualitas Audit. Jurnal NeO-Bis, 7(2), 1-17.

Radecki, C. M. \& Jaccard, J. (1995). Perceptions of knowledge, actual knowledge, and information search behavior. Journal of Experimental Social Psychology, 31(2), 107-138. https://doi.org/10.1006/jesp.1995.1006

Rowley, J. E. (2002). Reflections on customer knowledge management in e-business. Qualitative Market Research: An International Journal, 5(4), 268-280. https://doi.org/10.1108/13522750210443227

Sexton, R. S., Johnson, R. A. \& Hignite, M. A. (2002). Predicting Internet/e-commerce use. Internet Research, 12(5), 402-410. https://doi.org/10.1108/10662240210447155

Sheth, J. N., Newman, B. I. \& Gross, B. L. (1991). Why We Buy What We Buy: A Theory of Consumption Values. Journal of Business Research, 22(2), 159-170.

Ślusarczyk, B. (2018). Industry 4.0 - Are we ready? Polish Journal of Management Studies, 17(1), $232-248$. https://doi.org/10.17512/pjms.2018.17.1.19

Teo, T. S. H. \& Yeong, Y. D. (2003). Assessing the consumer decision process in the digital marketplace. Omega, 31(5), 349-363. https://doi.org/10.1016/S0305-0483(03)00055-0

Vaidya, S., Ambad, P. \& Bhosle, S. (2018). Industry 4.0 - A Glimpse. In 2nd International Conference on Materials Manufacturing and Design Engineering 2nd International Conference on Materials Manufacturing and Design Engineering (Vol. 20, pp. 233-238). Elsevier B.V. https://doi.org/10.1016/j.promfg.2018.02.034

Wilde, S. (2011). Customer Knowledge Management: improving customer relationship through knowledge application. Springer Science \& Business Media.

Witkowski, K. (2017). Internet of Things, Big Data, Industry 4.0 - Innovative Solutions in Logistics and Supply Chains Management. In 7th International Conference on Engineering, Project, and Production Management Internet (Vol. 182, pp. 763-769). The Author(s). https://doi.org/10.1016/j.proeng.2017.03.197

Yazdi, M. (2012). E-Learning sebagai Media Pembelajaran Interaktif Berbasis Teknologi Informasi. Jurnal Ilmiah Foristek, 2(1), 143-152.

Yulianti, R. (2016). Pengaruh Minat Masyarakat Aceh terhadap Keputusan Memilih Produk Perbankan Syariah di Kota Banda Aceh. Jurnal Dinamika Akuntansi Dan Bisnis, 2(1), 14-28. https://doi.org/10.24815/jdab.v2i1.3599 